\title{
Cadmium levels in oystercatcher Haematopus ostralegus from the German Wadden Sea
}

\author{
M. Stock ${ }^{1, *}$, R. F. M. Herber ${ }^{2}$, H. M. A. Gerón ${ }^{2}$ \\ ${ }^{1}$ University of Osnabrück, Department of Ethology, PO Box 4469, D-4500 Osnabrück, Federal Republic of Germany \\ ${ }^{2}$ Coronal Laboratorium for Occupational and Environmental Health, University of Amsterdam, Meibergdreef 15, 1105 AZ \\ Amsterdam, The Netherlands
}

\begin{abstract}
Cadmium levels of kidney and liver tissues of 150 oystercatcher Haematopus ostralegus frost victims from the German Wadden Sea area were determined by means of Electrothermal Atomization Absorption Spectrometry (ET-AAS). Overall median kidney values amounted to $11.9 \mu \mathrm{g}$ $\mathrm{g}^{-1}$, those of liver to $4.9 \mathrm{\mu g} \mathrm{g}^{-1}$ Because of tissue wastage, levels may be somewhat elevated compared to those in healthy birds. Females accumulated less cadmium than males. Accumulation of hepatic and renal cadmium was age-dependent, with subadult birds having significantly higher amounts than juveniles. There was no difference in concentration between subadult and adult birds. Overall, cadmium concentrations in kidney and liver tissues were strongly, positively, linearly correlated. No correlation between feather and tissue cadmium concentrations was found. A possible cadmium regulation mechanism for oystercatchers is discussed.
\end{abstract}

\section{INTRODUCTION}

The Wadden Sea is characterized by a high primary (Cadée \& Hegeman $1974 \mathrm{a}$, b) and secondary production (Beukema 1976, Wolff 1983). A considerable proportion of the zoobenthos is consumed by waders (Smit 1983, Baird et al. 1985). Data on the average daily consumption per bird species have shown that about $75 \%$ of the total zoobenthic consumption is taken by only 5 carnivorous species, with oystercatcher Haematopus ostralegus ranking second (Smit 1983).

Levels of certain heavy metals are often elevated in the sediments as well as in the invertebrate fauna in coastal environments (Förstner 1980, Bryan 1984, Salomons \& Förstner 1984). Cadmium is a well-known toxic and nonessential element showing a nearly 20 -fold increase in the Wadden Sea within sediments the last 200 yr (Förstner \& Reineck 1974). Between sediment, sea water, and biota remarkable interactions exist. Heavy metals bound to the sediment or to suspended particulate matter in the seawater can be accumulated in all marine organisms (Cooke et al. 1979, Loring \& Prosi 1986). The action of filter feeding is thought to give rise to this effect, particularly in molluscs, and therefore it is not surprising to find heavy metals often concentrated in the gills (Cooke et al. 1979).

\footnotetext{
- Addressee for reprint requests

In the Wadden Sea oystercatchers eat mainly molluscs, and to a lesser extent worms and crustaceans. Of the molluscs cockles Cerastoderma edule, mussels Mytilus edulis and Baltic tellins Macoma balthica are the main prey species. The Baltic tellin is taken when cockles are not available. Of the annelid worms, lugworm Arenicola marina and ragworm Nereis diversicolor are the chief species taken. Other prey species play a minor role (Hulscher 1985). Of all these, mussels are known to be the most sensitive indicators to elevated concentrations of heavy metals, particularly cadmium. Within the food-chain mussels, and to a lesser extent cockles, accumulate high levels or certain heavy metals (von Westernhagen et al. 1978, Buchwald et al. 1985). These and other diets of waders and shorebirds are contaminated with heavy metals (Packer et al. 1970, Evans \& Moon 1981, Zunk 1988).

In general, little is known about trace metal pollution in waders. Hutton (1981) investigated the accumulation of heavy metals and selenium in the oystercatcher. Further results are available from other wading species, e.g. dunlin Calidris alpina, knot Calidris canutus, curlew Numenius arquata, curlew sandpiper Calidris ferruginea, redshank Tringa totanus and bartailed godwit Limosa lapponica (Ward 1978, Evans \& Moon 1981, Goede \& de Bruin 1984, 1985, Goede 1985 , 1988, Goede \& de Voogt 1985, Blomqvist et al. 1987). Because of this lack of information we used an excep- 
tional opportunity to measure cadmium levels in liver and kidney tissues as well as in tail-feathers of oystercatchers.

\section{MATERIALS AND METHODS}

Birds. A prolonged frost period in winter 1986/87 caused large parts of the tidal flats in the Wadden Sea to freeze over. Thousands of waders, particularly oystercatchers, died in the German part of the area. Feeding opportunities were dratistically reduced and the body condition of the birds quickly decreased. All frost victims collected had an extremely low mean body weight. Nearly 3000 oystercatchers were found dead within only a few days. Of these, more than 900 were found on high tide roosts on the Isle of Wangerooge. A total of 354 birds were collected immediately after a first die off in January 1987 and studied in detail. All birds were measured, aged, sexed, weighed, and the form of the bill and bill-tip was noted; these results will be given elsewere (Stock unpubl.).

Organ and feather sampling. From randomly chosen individuals liver $(n=149)$ and kidney samples $(n=60)$ were taken. Sampling was done using stainless steel scissors and forceps to avoid contamination. Tissues were stored in polyethylene vessels until subsequent treatment. Additionally the innermost tail-feather from a smaller randomly chosen subsample $(n=30)$ was collected and placed into labeled plastic bags.

Sample preparation. Immediately after removal, the organ tissues were freeze-dried for $48 \mathrm{~h}$ and then homogenized with an agate mill. The dried samples were stored in clean polyethylene vessels at $4^{\circ} \mathrm{C}$. All the laboratory material involved in destruction and storage was cleaned by immersion in 1:20 diluted $\mathrm{HNO}_{3}$ overnight and subsequently rinsing with deionised water. To avoid further contamination, pulverised samples were handled with teflon-coated instruments. Two aliquots of 5 to $10 \mathrm{mg}$ of dried organ tissues were digested with $100 \mu$ of a mixture of concentrated $\mathrm{HNO}_{3}: \mathrm{H}_{2} \mathrm{SO}_{4}$ (4:1, Merck Suprapur) in polyethylene cups overnight (Sperling et al. 1977, Sperling \& Bahr 1979). Afterwards the cooled samples were diluted with $900 \mu$ deionised water and stored in the same cups at $4{ }^{\circ} \mathrm{C}$. During this process a blank - acid without tissue sample - was also induced every day. These 1:10 diluted samples can be stored for some weeks until further dilution and analysis.

To remove superficial contamination, feathers were sonicated in a $0.01 \%$ Triton-X-100 solution for $2 \mathrm{~min}$. Subsequently the cleaned feathers were dried at $80^{\circ} \mathrm{C}$ overnight. The vane was clipped from the shaft with stainless steel scissors. Only the vane was analysed.

Analysis. Electrothermal Atomization Absorption Spectrometry (ET-AAS) with deuterium background correction was applied. Operating conditions for the equipment as well as the temperature program of the atomizer are given in Table 1 . Instrument settings were chosen according to manual instructions and optimizing procedures. Due to aging of the graphite tubes, alterations occur and may sometimes lead to signal drift effects and signal reduction. Therefore the tubes were changed after ca 150 firings. To obtain reproducible results numerous control determinations of reference material were required. Consequently every tenth sample cup contained a control sample with a known cadmium concentration. NBS bovine liver 1577 a was taken as reference material and analysed daily together with the samples. A stock solution of $1000 \mathrm{mg}$ $\mathrm{kg}^{-1} \mathrm{Cd}$ was prepared by dissolving metallic cadmium shots (Alfa Products, USA) in $1 \% \mathrm{HNO}_{3}$ Suprapur (Merck, FRG). The concentration was controlled by titration. Aqueous acidified standards in the range 0 to $3 \mu \mathrm{g} \mathrm{kg}{ }^{-1}$ were prepared daily Since the standardaddition method for large series of determinations with the same matrix is unnecessarily intricate, aqueous acidified standards were chosen to evaluate cadmium concentration. This method is possible when the cadmium concentration of the original sample is high enough to allow a more than 20 -fold dilution. In this case the standard curves from acidified solution fit exactly to those obtained from spiked material (Sper)ing et al. 1977). The detection limit of the method was

Table 1. Instrument settings for the analysis of cadmium in oystercatcher tissues

Instrument

Wavelength / slit Lamp current Injection Replicate firings Determination conditions Drying Ashing Atomization Tube cleaning
VARIAN AA 1275, GTA 95, Graphite-Tube-Atomizer with PSV Auto Sampler and $\mathrm{D}_{2}$ Background Correction. $228.8 \mathrm{~nm} / 0.2-0.3 \mathrm{~nm}$

$4 \mathrm{~mA}$

$10 \mu l$ at ambient temperature 2

Absorbance/gasstop/peak height mode

$95^{\circ} \mathrm{C}$, ramp $10 \mathrm{~s} ; 120^{\circ} \mathrm{C}$, ramp 5 , hold $35 \mathrm{~s}$

$250^{\circ} \mathrm{C}$, ramp 15 , hold $16 \mathrm{~s}$

$1600^{\circ} \mathrm{C}$, ramp 0.7 , hold $2 \mathrm{~s}$

$2500^{\circ} \mathrm{C}$, ramp $3 \mathrm{~s}$ 
$0.02 \mu \mathrm{g} \mathrm{g}^{-1}$, the repeatability of the determinations $95.4 \%$. The recovery value amounted to $99.7 \%$. All tissue and feather concentrations are given as $\mu \mathrm{g} \mathrm{g}^{-1}$ dry matter.

Data handling. Since the cadmium concentrations were non-randomly distributed, we evaluated arithmetic means with standard deviations, geometric means, harmonic means and medians of the data set. To randomize the data, decadic logarithmic transformation was carried out. The results were checked by a chisquare adaptation test. Parametric correlation and regression analysis were carried out with these transformed data. Non-parametric tests were done with original data. Calculations were performed with standard statistical procedures using the STATPAK Statistic Package (Northwest Analytical 1983).

\section{RESULTS}

\section{Cadmium body burden and sex}

Tissue and feather cadmium concentrations of oystercatchers from the German Wadden Sea are shown in Table 2. Highest values derived as arithmetic, harmonic or geometric means or medians were found in the kidney, with appreciable amounts in liver, but low levels in feathers. Overall, females accumulated less cadmium than males (Table 2). Differences in liver concentrations between the sexes are significant (Mann-Whitney-test, $p<0.07$ ). This is also true when looking at juveniles only (Mann-Whitney-test, $p<$ 0.04), but not for subadults and adults.
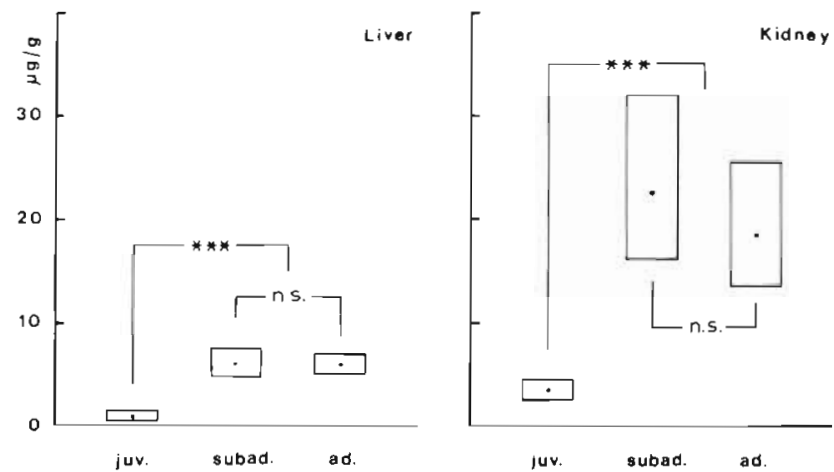

Fig. 1. Haematopus ostralegus. Age-dependent cadmium concentration (median and confidence interval; $\mu \mathrm{g} \mathrm{g}^{-1}$ ) in oystercatcher liver $(n=149)$ and kidney tissues $(n=59)$ from the German Wadden Sea. (Mann-Whitney-test; $\cdots p<0.001$; ns: not significant)

\section{Age-dependent cadmium accumulation}

Fig. 1 shows that accumulation of hepatic and renal cadmium is age-dependent, with subadult birds having significantly higher amounts than juveniles (MannWhitney-test, $p<0.001$ ). The differences were greatest for the kidney tissues, with an average 6.3-fold difference (Mann-Whitney-test, $p<0.001$ ) between juvenile and subadult oystercatchers. The corresponding factor for liver tissues was a 4.2 -fold difference $(p<0.001)$. There was no difference in concentrations between subadult and adult birds. Hepatic values in subadult and adult birds were similar whereas renal cadmium concentrations in adult birds were slightly lower than in subadults; however, the differences are not significant.

Table 2. Haematopus ostralegus. Cadmium concentration ( $\mu \mathrm{g} \mathrm{g}^{-1} \mathrm{dry}$ matter) in organ tissues and feathers from a total of 149 oystercatchers. HM: harmonic mean; GM: geometric mean; AM: arithmetic mean; \pm SD: \pm 1 standard deviation; M: median; $\mathrm{CM}$ : confidence interval of median. Range is also given

\begin{tabular}{|c|c|c|c|c|c|c|c|c|}
\hline & $n$ & HM & GM & $A M$ & $\pm S D$ & M & CM & Range \\
\hline \multicolumn{9}{|c|}{ Cadmium - liver $\left(\mu \mathrm{g} \mathrm{g}^{-1}\right)$} \\
\hline Juvenile & 24 & 1.15 & 1.34 & 1.56 & 0.92 & 1.43 & $1.11-1.79$ & $0.46-3.83$ \\
\hline Subadult & 53 & 3.76 & 5.62 & 8.36 & 8.27 & 5.98 & $4.70-7.57$ & $0.76-41.57$ \\
\hline Adult & 72 & 4.28 & 5.64 & 7.42 & 6.18 & 5.89 & $4.96-6.96$ & $0.97-35.94$ \\
\hline Male & 85 & 3.78 & 5.27 & 7.58 & 7.64 & 5.57 & $4.65-6.64$ & $1.00-41.57$ \\
\hline Female & 62 & 2.21 & 3.64 & 5.83 & 5.83 & 4.07 & $3.17-5.17$ & $0.46-32.40$ \\
\hline \multicolumn{9}{|c|}{ Cadmium - kidney $\left(\mu \mathrm{g} \mathrm{g}^{-1}\right)$} \\
\hline Juvenile & 20 & 3.11 & 3.50 & 3.94 & 2.04 & 3.59 & $2.82-4.49$ & $1.24-9.17$ \\
\hline Subadult & 21 & 16.39 & 22.42 & 29.05 & 19.79 & 22.76 & $15.94-32.34$ & $5.18-70.87$ \\
\hline Adult & 19 & 14.84 & 18.37 & 22.39 & 13.36 & 18.59 & $13.45-25.61$ & $5.23-42.03$ \\
\hline Male & 27 & 7.28 & 12.47 & 20.67 & 19.57 & 13.08 & $8.53-19.80$ & $2.11-70.87$ \\
\hline Female & 31 & 6.03 & 10.19 & 16.80 & 16.04 & 10.77 & $7.29-15.71$ & $1.24-66.06$ \\
\hline \multicolumn{9}{|c|}{ Cadmium - feather $\left(\mu \mathrm{g} \mathrm{g}^{-1}\right)$} \\
\hline Overall & 30 & 0.13 & 0.18 & 0.21 & 0.11 & 0.21 & $0.17-0.25$ & $0.02-0.49$ \\
\hline
\end{tabular}




\section{Cadmium in tail-feathers}

Cadmium concentrations in feather vanes are relatively low. They amounted to $0.21 \pm 0.11 \mathrm{gg} \mathrm{g}^{-1}$. Since we found a normal cadmium distribution in the feathers the arithmetic mean gives the best representation of the data (Table 2). We found no significant correlation between cadmium concentrations in the tissues and the feathers (correlation coefficient between feather and liver: $r=-0.24, n=30$; between feather and kidney: $r=-0.27, n=30$ ).

\section{Inter-organ cadmium correlations}

We calculated inter-organ correlations by means of linear correlation analysis with log-transformed data. There was a positive correlation (Fig. 2) between kid-

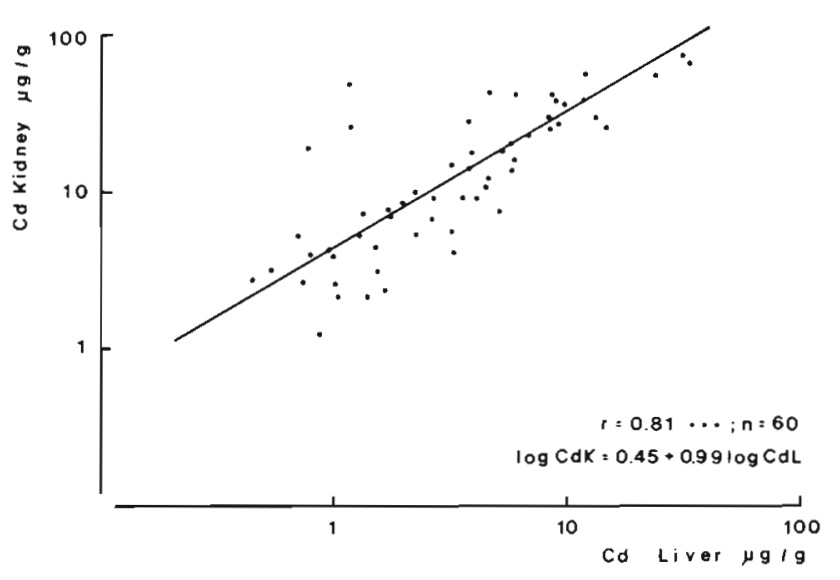

Fig. 2. Haematopus ostralegus. Relation between cadmium concentration in kidney versus liver tissues of all oystercatchers examined $(n=60)$. Logarithmically transformed data. ( $\cdots$ $p<0.001$; CdK: cadmium in kidney; CdL: cadmium in liver)

ney and liver cadmium concentrations ( $p<0.001$ ). If we subdivided the sample according to sex similar correlations with the same slope of the regression line occurred. The correlation coefficient for males was 0.78 $(n=27)$, and for females $0.88(n=31)$. Both correlations were also significant $(p<0.001)$.

A different picture emerges when comparing the 3 age classes (Fig. 3). Correlation coefficients and significance levels between kidney and liver tissue cadmium concentrations increased with the age of the birds: juveniles, $r=0.49, p<0.05, n=20$; subadults, $r=0.59$, $p<0.01, n=21$; adults, $r=0.90, p<0.001, n=19$. The slopes of the regression lines behave differently. For juvenile and subadult birds the ratio of liver to kidney concentration was similar: only a weak renal cadmium increase occurred with rising hepatic concentrations. The regression coefficient amounted to 0.61 in juveniles, and 0.51 in subadults. In adult birds the slope is in
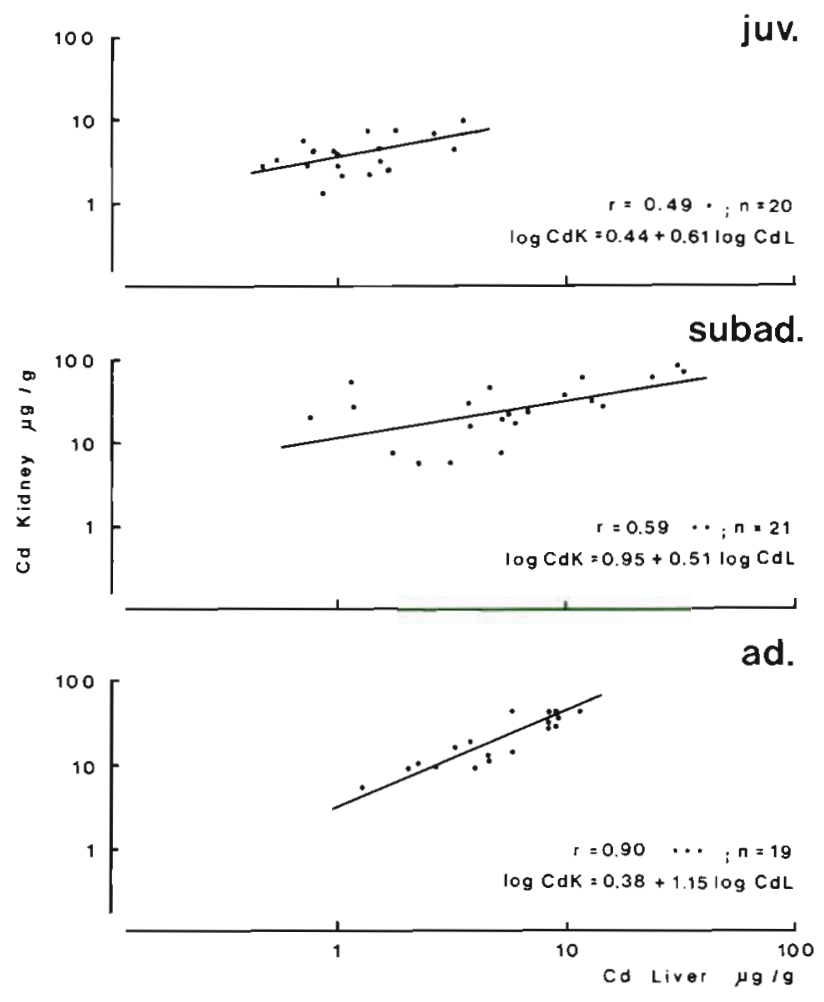

Fig. 3. Haematopus ostralegus. Relation between cadmium concentration in kidney versus liver tissues in juvenile, subadult, and adult oystercatchers. Logarithmically transformed data $\left({ }^{*} p<0.05, \cdots p<0.01, \cdots p<0.001\right)$

accordance with an assumed reference line (equal cadmium level in both organs). The regression coefficient amounted to 1.15 .

\section{DISCUSSION}

Once absorbed, cadmium is retained in the body and usually only a small proportion is excreted. Nordberg (1974) quoted a mean retention rate of 0.5 to $3 \%$ in humans which depends on the protein, calcium, and vitamin D content of the food. Evans et al. (1987) investigated curlews in Great Britain and calculated a retention rate of less than $1 \%$.

Cadmium absorption takes place mostly in 2 ways: from the air by inhalation or by oral uptake. It is transported via the blood to other parts of the body where 50 to $75 \%$ is stored in only 2 organs, the kidney and the liver. Here the cadmium is bound to metallothionein, a cadmium-specific binding protein (Nordberg 1974, Stoeppler 1984, Herbert et al. 1988). The kidney cortex is of critical importance and functions as a longterm store. The kidney therefore accumulates cadmium for the whole life span (Nordberg 1974).

In birds little is known about the effect of cadmium. Lofts \& Murton (1967) and White et al. (1978) found that 
high doses of cadmium caused lesions and atrophy of the testes in pigeons Columba livia and mallards Anas platyrhynchos. White et al. were able to show that mallards fed with high cadmium doses lost their spermatogenetic activities. Nicholson \& Osborn (1983) showed patchy nephrotoxic lesions due to natural cadmium exposure in pelagic seabirds. In view of histological nephrotoxicities Nicholson et al. (1983) compared kidney tissues of seabirds from an uncontaminated colony with those of cadmium-dosed starlings and mice. They found that the cadmium concentrations at which damage began were below those presently considered as relatively safe for human beings. When assessing the potential impacts of environmental pollutants such as heavy metals on animals Di Giulio \& Scanlon (1985) concluded from their findings in mallards that interactions exist between contaminants and naturally occurring environmental stressors.

When measuring heavy metals in tissues of birds it is usual to choose healthy individuals. This is done because other individuals, e.g. birds starved to death, as in our case, could show tissue wastage. To check whether age-related different tissue losses occurred we measured the total liver weight from a smaller subsample of 10 adult and 10 juvenile oystercatchers. Liver weight averaged $7.8 \pm 0.54 \mathrm{~g}$ in adults and $7.5 \pm 0.9 \mathrm{~g}$ in juveniles. Furthermore the fat-free dry liver weight in both age classes amounted to $1.5 \pm 0.3 \%$ of fat-free dry body weight (Nehls unpubl.). Thus we can assume that our results remain comparable between age classes. However it must be taken in account that our measurements of renal and hepatic cadmium concentrations may be raised by a certain degree of tissue wastage. This must be considered when direct comparisons are made with levels of heavy metals in healthy birds.

In contrast to other waders, oystercatchers have elevated renal and hepatic cadmium concentrations. The internal distribution patterns found in this study agree with those found in other studies (Hutton \& Goodman 1980, Hutton 1981, Evans et al. 1987). Oystercatchers in this study showed a 2 -fold elevated cadmium concentration in liver tissues and a nearly 3 -fold elevation in kidney tissues in comparison with other wading species taken as healthy birds from different localities in the Wadden Sea (Ward 1978, Evans \& Moon 1981, Goede $\&$ de Bruin 1984, 1985, Goede 1985, Goede \& de Voogt 1985, Blomqvist et al. 1987, Evans et al. 1987, Goede et al. in press). To what degree this elevation is due to a tissue wastage remains unclear. According to results obtained by Hutton (1981), the same species from tidal flats in the UK had somewhat higher cadmium levels than birds from the German Wadden Sea. Heidmann et al. (1987) investigated residues of chlorinated hydrocarbons and heavy metals in a small number of oystercatchers ( $n=15)$ from the same locality as our specimens. They found a high PCB and mercury concentration in liver tissues but a negligible cadmium content in the same organ. Since no data about the age of the birds were given, and also because of the small number of birds examined, it is difficult to comment on the low concentration of $1.4 \mu \mathrm{g} \mathrm{g}^{-1}$ dry matter (recalculated) in that study

In any case, the highest renal cadmium concentration found in this study $\left(70.9 \mu \mathrm{g} \mathrm{g}^{-1}\right)$ is still lower than the concentrations found to cause histological kidney lesions in other seabirds (Nicholson \& Osborn 1983. Nicholson et al. 1983). In considering these results it must be borne in mind that extrapolations from one species to another will be influenced by various parameters. Age, sex, feeding habits, locality of collection, time of year and the species itself may all have an effect. Data on the effect of feeding habits on cadmium tissue content will be published elsewhere (Stock unpubl.). Ward (1978) and Osborne (1979) found seasonal variations in the tissue metal content of birds, and Evans et al. (1987) found site-dependent differences in the heavy metal concentration of organ tissues in waders on wintering grounds in the UK.

Cadmium concentrations in feathers are hardly to be found in the literature. Goede \& de Bruin (1984) and Goede \& de Voogt (1985) found cadmium concentrations in the vane of juvenile and newly formed adult primary flight feathers in the range 0.07 to $0.49 \mu \mathrm{g} \mathrm{g}^{-1}$ They took feather samples from dunlin, knot and bartailed godwit. Our findings are within this range and can be considered as relatively low. No correlation between tissue cadmium and feather content was found. The same was reported by Osborne et al. (1979) in 3 pelagic seabird species and from several wader species from the Wadden Sea area (Goede \& de Bruin 1984, Goede \& de Voogt 1985). Based on the findings of the latter authors and the present results we conclude that feathers are of no value as indicators in monitoring tissue cadmium concentrations in birds. On the other hand there is evidence that the cadmium content of standardized feathers reflects environmental contamination with cadmium, as recently found in magpies Pica pica (Hahn \& Ellenberg in press).

Cadmium was found in lower amounts in the livers of female oystercatchers than in males. When lumping all age-classes together a weak significant level appears (Mann-Whitney-test, $p<0.08$ ). This is in contrast to the findings of Hutton (1981). He found significantly higher renal cadmium in females but an equal hepatic cadmium level. He assumed that this was due to increased intestinal calcium absorption during eggshell building. An induced calcium-binding protein during this phase has a similar affinity to cadmium, and consequently cadmium uptake should be increased. Cadmium can 
be excreted via urine, and possibly through nasal salt glands and preen glands (Goede \& de Bruin 1984 , Evans et al. 1987). To a lesser extent a seasonal excretion occurs through the feathers during moult.

Oystercatchers show sexual size dimorphism, and from cage experiments and field observations it is known that females may take different foods than males. They feed more often on open tidal flats than males which occur more often on musselbeds (Swennen et al. 1983, Hulscher 1985). These differences in feeding habits, and consequently food types, could also explain the differences in the cadmium content of the sexes.

Cadmium is known to occur at higher concentrations in adults than in juvenile birds. This has previously been found in oystercatcher (Hutton 1981), bar-tailed godwit (Evans \& Moon 1981), dunlin and curlew sandpiper (Blomquist et al. 1987), and in a number of other birds and sea mammals (Frank \& Borg 1979, Furness \& Hutton 1979, Karlog et al. 1983, Lang 1985). Although in this study subadult oystercatchers had a higher renal and hepatic cadmium content than juveniles, there was no difference between the cadmium levels in subadult and adult birds. This pattern is difficult to explain though the following 4 hypotheses are suggested. (1) The high metabolic rate in subadult birds during continued growth would cause an increased cadmium concentration. Frank (1986) recently could show that a strong cadmium increase in juvenile eider ducks takes place within the first $10 \mathrm{~d}$ of their life. Renal cadmium values reached a level equal to the mean kidney level of adult birds from the same study area. (2) Very high cadmium concentrations are known to cause histological lesions of renal tubuli in humans (Maker 1981). This leads to tissue, and thus cadmium, loss (Roels et al. 1981). Consequently the tissue concentration could also be reduced in older birds. (3) Cadmium is a toxic metal and very old birds (adults) may have died as a result of strongly elevated cadmium concentrations and would therefore be missing from the sample. (4) There is the interesting possibility that oystercatchers may have a cadmium regulation mechanism. A similar agerelated concentration pattern to that found in this study was demonstrated in herring gulls Larus argentatus (Zunk 1984). Birds of known age, subdivided into 6 age classes, showed a steady renal and hepatic cadmium increase up to age 3 yr but afterwards this increase ceased. This is in agreement with our findings and those of Nicholson (1981). Herring gulls aged between 4 and 11 yr did not show any age-related increase in cadmium levels in the liver and kidney tissues. Nicholson assumed that these birds were receiving a level of exposure low enough for them to balance cadmium input with excretion. Although cadmium concentrations in herring gulls in both studies were somewhat lower than those recorded in oystercatchers, it is possible that both oystercatchers and herring gulls are able to cope with the toxin (Stock unpubl.).

Overall, cadmium concentrations in kidney versus the liver tissues were strongly, positively and linearly correlated. This holds for both sexes. When looking at the different age classes we found different slopes of the regression lines. Juvenile and subadult birds were similar but show a reduced renal to hepatic cadmium ratio compared to adults. Similar regressions and correlations to those found in this study were also reported by Kühnast (1984) in eider ducks. Further direct comparisons with other bird species are not possible because logarithmically transformed data were rarely used. Nevertheless, for oystercatchers the results obtained here imply that cadmium metabolism may be better regulated with increasing age. This effect is age-, and not concentration-related, because cadmium levels in subadult and adult birds are equivalent, whereas the regression lines are different. This is also known in humans, where the renal to hepatic ratio of cadmium changes with age (Elinder 1985).

Acknowledgements. We thank the Nationalparkamt Niedersächsisches Wattenmeer, Wilhelmshaven, FRG for providing oystercatcher frost victims for the investigation. Many thanks also to Barbara Bahr and Klaus-Richard Sperling from the Biologische Anstalt Helgoland who gave one of us (M.S.) a first introduction into the ET-AAS technique. We are much indebted to Hans-Heiner Bergmann, University of Osnabrück, FRG, Lida Goede, Interfaculty Reactor Institute, Technical University Delft, NL, John Goss-Custard, Institute of Terrestrial Ecology, Wareham, UK, and to Jan Everaarts and Cees Swennen, Netherlands Institute for Sea Research, NL, for their critical comments on earlier drafts of the manuscript. We thank G. Nehls, University of Kiel, who made the unpublished live weight data available.

\section{LITERATURE CITED}

Baird, D., Evans, P. R., Milne, H., Pienkowski, M. W (1985). Utilization by shorebirds of benthic invertebrate production in intertidal areas. Oceanogr. mar Biol. A. Rev. 23: 573-597

Beukema, J. J. (1976). Biomass and species richness of the macro-benthic animals living on the tidal flats of the Dutch Wadden Sea. Neth. J. Sea Res. 10: 236-261

Blomquist, S., Frank, A., Petersson, L. B. (1987). Metals in liver and kidney tissues of autumn-migrating dunlin Calidris alpina and curlew sandpiper Calidris ferruginea at the Baltic Sea. Màr Ecol. Prog. Ser. 35: 1-13

Bryan, G. W. (1984). Pollution due to heavy metals and their compounds. In: Kinne, O. (ed.) Marine ecology. Vol. V. Ocean Management Part 3. Wiley, Chichester, p. 1289-1431

Buchwald, K., Rincke, G., Rudolph. K.-H. (1985). Umweltprobleme der Ostfriesischen Inseln. Hannover, Published by the authors

Cadée, G. C.. Hegemann, J. (1974a). Primary production of phytoplankton in the Dutch Wadden Sea. Neth. J. Sea Res. 8: $240-259$ 
Cadée, G. C., Hegemann, J. (1974b). Primary production of the benthic microflora living on the tidal flats in the Dutch Wadden Sea. Neth. J. Sea Res. 8: 260-291

Cooke, G. C., Nickless, G., Lawn, R. E., Roberts, D. J. (1979). Biological availability of sediment bound cadmium to the edible cockle, Cerastoderma edule. Bull. Environ. Contam. Toxicol. 23: 381-386

Di Giulio, R. T., Scanlon, P. F. (1985). Effects of cadmium ingestion and food restriction on energy metabolism and tissue concentration in mallard ducks. Environ. Res. 37: $433-444$

Elinder, C.-G. (1985). Normal values of cadmium in human tissues, blood, and urine in different countries. In: Friedberg, L., Elinder, C.-G., Kjellström, T., Nordberg, G. F. (eds.) Cadmium and health: a toxicological and epidemological appraisal. Vol 1. Exposure, dose, and metabolism. CRC Press, Boca Raton, Florida, p. 82-102

Evans, P. R., Moon, J. S. (1981). Heavy metals in shorebirds and their prey. In: Say, P. J., Whitton, B. A. (eds.) Heavy metals in northern england: environmental and biological aspects. Univ. of Durham, Durham, p. 181-190

Evans, P. R., Uttley, J. D., Davidson, N. C., Ward, P. (1987). Shorebirds (S.Os Charadrii and Scolaci) as agents of transfer of heavy metals within and between estuarine ecosystems. In: Coughtrey, P. J., Martin, M. H., Unsworth, M. H. (eds.) Pollutant transport and fate in ecosystems. Blackwell Publ., Oxford, p. 337-352

Förstner, U. (1980). Inorganic pollutants, particularly heavy metals in estuaries. In: Olausson, E. Cato, I. (eds.) Chemistry and biogeochemistry of estuaries. Wiley, Chichester, p. $307-348$

Förstner, U., Reineck, H.-E. (1974). Die Anreicherung von Spurenelementen in den rezenten Sedimenten eines Profilkerns aus der Deutschen Bucht. Senckenberg. maritima 6: $175-184$

Frank, A. (1986). In search of biomonitors for cadmium: cadmium content of wild Swedish fauna during 1973-1976. Sci. Total Environ. 57: 57-65

Frank, A., Borg, K. (1979). Heavy metals in tissues of the mute swan (Cygnus olor). Acta Vet. Scand. 20: 447-465

Furness, R., Hutton, M. (1979). Pollutant levels in the great skua Catharcta skua. Environ. Pollut. 19: 261-268

Goede, A. A. (1985). Mercury, selenium, arsenic and zinc in waders from the Dutch Wadden Sea. Environ. Pollut. 37: 287-309

Goede, A. A. (1988). Element composition of feathers characterized knot Calidris canutus: a testcase. Wader Study Group Bull. No. 52: 11-14

Goede, A. A., de Bruin, M. (1984). The use of bird feather parts as a monitor for metal pollution. Environ. Pollut. 8: 281-298

Goede, A. A., de Bruin, M. (1985). Selenium in a shore-bird, the dunlin, from the Dutch Waddenzee. Mar. Pollut. Bull. 16: $115-117$

Goede, A. A., de Voogt, P. (1985). Lead and cadmium in waders from the Dutch Wadden Sea. Environ. Pollut. 37: 311-322

Goede, A. A., Nygaard, T., de Bruin, M., Steinners, M. (in press). Selenium, mercury, arsenic and cadmium in the lifecycle of the dunlin Calidris alpina, a migrant wader Sci. Total Environ.

Hahn, E. Ellenberg, H. (in press). Schwermetallgehalte in Federn von Elstern - Folge exogener Auflagerung aus der Atmosphäre. Verh. Ges. Ökologie

Heidmann, W., Büthe, A., Peterat, B., Knüver, H. (1987). Zur Frage des Einflusses chemischer Rückstände auf das Sterben von Austernfischern (Haematopus ostralegus) an der niedersächsischen Küste im Winter 1986/87 Vogelwarte 34: $73-79$
Herber, R. F. M., Verschoor, M. A., Wibowo, A. A. E. (1988). A review of the kinetics and kidney effects of cadmium recent epidemiological studies. Environ. Toxin Series 2. In: Stoeppler, M., Piscator, M. (eds.) Cadmium. Springer, Berlin, p. $115-133$

Hulscher, J. B. (1985). Growth and abrasion of the oystercatcher bill in relation to dietary switches. Neth. J. Zool. 35: $124-154$

Hutton, M. (1981). Accumulation of heavy metals and selenium in three seabird species from the United Kingdom. Environ. Pollut. 26: 129-145

Hutton, M., Goodman, G. T. (1980). Metal contamination of feral pigeons (Columba Livia) from the London area. Part 1 Tissue accumulation of lead, cadmium and zinc. Environ. Pollut. 22: 207-217

Karlog, O., Elvestad, K., Clasen, B. (1983). Heavy metals (cadmium, copper, lead and mercury) in common eiders (Somateria mollissima) from Denmark. Nord. Vet. - Med. 35: $448-451$

Kühnast, O. (1984). Untersuchungen zur Cadmium-Belastung von Eiderente, Eisente und Trauerente von der Ost- und Nordsee. Diplom thesis, Univ. of Hamburg

Lang, D. (1985). Untersuchungsergebnisse zur Schadstoffbelastung von Seehunden aus dem Wattenmeer, Schleswig-Holstein. Säugetierkdl. Mittlg. 32: 281-292

Lofts, B., Murton, R. K. (1967). The effect of cadmium on the avian testis. J. Reprod. Fert. 13: 155-164

Loring, D. H., Prosi, F. (1986). Cadnium and lead cycling between water, sediment and biota in an artificially contaminated mud flat on Borkum. Wat. Sci. Tech. 18: $131-139$

Maker, J. F. (1981). Toxic nephropathy. In: Brenner, B. M., Rector, F. C. (eds.) The kidney, Capter 31. W. B. Saunders Co, Philadelphia

Nicholson, J. K. (1981). The comparative distribution of zinc, cadmium and mercury in selected tissues of the herring gull (Larus argentatus). Comp. Biochem. Physiol. 68 C: 91-94

Nicholson, J. K., Kendall, M. D., Osborn, D. (1983). Cadmium and mercury nephrotoxicity. Nature, Lond. 304: 633-635

Nicholson, J. K., Osborn, D. (1983). Kidney lesions in pelagic seabirds with high levels of cadmium and mercury. J. Zool., Lond. 200: 99-118

Nordberg, G. F. (1974). Health hazards of environmental cadmium pollution. Ambio 3: 55-66

Northwest Analytical (1983). NWA Statpak: multifunction statistics library. Portland, Oregon

Osborn, D. (1979). Seasonal changes in the fat, protein and metal content of the liver of the starling Sturnus vulgaris. Environ. Pollut. 19: 145-155

Osborn, D., Harris, M. P., Nicholson, J. K. (1979). Comparative tissue distribution of mercury, cadmium and zinc in three species of pelagic seabirds. Comp. Biochem. Physiol. 64: $61-67$

Packer, D. M., Ireland, M. P., Wootton, R. J. (1980). Cadmium, copper, lead, zinc and manganese in the polychaete Arenicola marina from sediments around the coast of Wales. Environ. Pollut. 22: 309-321

Roels, H. A., Lauwerys, R. R., Buchet, J. P., Bernhard, A., Chettle, D. R., Harvey, T. C., Al-Haddad, I. K. (1981). In vivo measurement of liver and kidney cadmium in workers exposed to this metal: its significance with respect to cadmium in blood and urine. Environ. Res. 26: 217-240

Salomons, W., Förstner, U. (1984). Metals in the hydrocycle. Springer, Berlin

Smit, C. J. (1983). The importance of the Wadden Sea for estuarine birds. In: Wolff, W. J. (ed.) Ecology of the Wadden Sea. Balkema, Rotterdam, p. 280-289 
Sperling, K. R., Bahr, B. (1979). Determination of heavy metals in sea water and marine organisms by flameless atomic absorption spectrophotometry. VIII Digestion of biological materials. Z. Lebensm. Unters. Forsch. 168: 193-194

Sperling, K. R., Bahr, B., Kremling, K. (1977). Heavy metal determination in sea water and in marine organisms with the aid of flameless AAS. IV. Description of a routine method for the determination of Cadmium in small sample of biological material. Z. Lebensm. Unters. Forsch. 163: $87-91$

Stoeppler, M. (1984). Cadmium. In: Merian, E. (ed.) Metalle in der Umwelt. Verteilung, Analytik und biologische Relevanz. Verlag Chemie, Weinheim, p. 375-408

Swennen, C., de Bruin, L. M. Duiven, P., Leopold. M. F., Martijn, E. C. L. (1983). Differences in bill form of the oystercatcher Haematopus ostralegus, a dynamic adaptation to specific foraging techniques. Neth. J. Sea Res. 17: 57-83

Ward, P. (1978). Heavy metals in waders. ITE Report 1978 $56-57$

This article was submitted to the editor
Westernhagen, H. von, Dethlefsen, V., Rosenthal, H., Fürstenberg, G., Klinckmann, J. (1978). Fate and effects of cadmium in an experimental marine ecosystem. Helgoländer wiss. Meeresunters. 31. 471-484

White, D. H., Finley, M. T., Ferrell, J. F. (1978). Histopathological effects of dietary cadmium on kidney and testes of mallard ducks. J. Toxicol. Environ. Health 4: 551-558

Wolff, W. J. (1983). Estuarine benthos. In: Ketchum, B. H. (ed.) Estuaries and enclosed seas. Ecosystems of the world 26. Elsevier, Amsterdam, p. 151-182

Zunk, B. (1984). Über die Cadmiumbelastung einiger Möwenarten aus dem Bereich der Deutschen Bucht. In: Welz, B. (ed.) Fortschritte in der atomspektrometrischen Spurenanalytik. Bd. 1. Verlag Chemie, Weinheim, p. 597-607

Zunk, B. (1988). Die Cadmiumbelastung zweier Polychaetenarten und der Sedimente im Wattenmeerbereich der Deutschen Bucht unter Berücksichtigung hydrographischer und geochemischer Einflüsse. Dissertation, Univ. of Hamburg

Manuscripi first received: December 13,1988 Revised version accepted: February 21, 1989 